\title{
What an Emerging Trump Administration Means for Lesbian, Gay, Bisexual, and Transgender Health
}

\author{
Gilbert Gonzales ${ }^{1, *}$ and Tara McKay ${ }^{2}$
}

\begin{abstract}
The policies of the Trump administration are likely to have direct and indirect implications for lesbian, gay, bisexual, and transgender (LGBT) health. With the assistance of a Republican-controlled Congress, President Trump may repeal President Obama's health reform law, undermine same-sex marriage laws and other nondiscrimination protections, reduce funding for research on sexual and gender minority health, and institutionalize discrimination through new legislation, such as the First Amendment Defense Act. Public health researchers, healthcare providers, and professional organizations must continue to combat discrimination and advocate for LGBT health equity under an emerging Trump presidency.
\end{abstract}

Keywords: election; health disparities; public policy and advocacy

\section{Introduction}

On November 8, 2016, Donald J. Trump defied public opinion polls and election experts when he defeated Hillary Clinton in the 2016 election for the presidency of the United States. Meanwhile, Republicans maintained control of the U.S. House of Representatives and the U.S. Senate, and they increased their control at the state level-holding both legislative chambers in 32 states. ${ }^{1}$ Although President Trump's policy positions are still materializing, the anticipated policy positions of the Trump administration may have direct and indirect implications for lesbian, gay, bisexual, and transgender (LGBT) health.

\section{The Affordable Care Act}

On the campaign trail, President Trump repeatedly vowed to repeal and replace President Obama's signature healthcare reform law, the Affordable Care Act (ACA), which extended health insurance coverage to more than 20 million Americans since its enactment in 2010. ${ }^{2}$ Through health insurance reforms (e.g., pre-existing condition exclusion bans, annual and lifetime limit prohibitions, guaranteed issue, and community rating), expansions in Medicaid for low-income residents, and subsidies for middle-income Americans to purchase private health insurance through the Marketplaces, millions of previously uninsured Americans gained health insurance for the first time-including many LGBT people. ${ }^{3,4}$

Moreover, the ACA extended new protections for sexual and gender minorities (SGMs) in healthcare. Specifically, Section 1557 under the ACA prohibits healthcare providers and facilities receiving federal funds from discriminating against individuals based on sex, which the Office for Civil Rights (OCR) at the Department of Health and Human Services (HHS) determined included gender identity and sex stereotypes. ${ }^{5}$ In addition, under the ACA, public health plans (e.g., Medicare and Medicaid) and health plans sold on the Marketplaces can no longer categorically deny health

\footnotetext{
${ }^{1}$ Department of Health Policy, Vanderbilt University School of Medicine, Nashville, Tennessee.

${ }^{2}$ Center for Medicine, Health and Society, Vanderbilt University, Nashville, Tennessee.
}

*Address correspondence to: Gilbert Gonzales, PhD, MHA, Department of Health Policy, Vanderbilt University School of Medicine, 2525 West End, Suite 1200, Nashville, 37203, TN, E-mail: gilbert.gonzales@vanderbilt.edu

(c) Gilbert Gonzales and Tara McKay 2017; Published by Mary Ann Liebert, Inc. This is an Open Access article distributed under the terms of the Creative Commons Attribution License, which permits unrestricted use, distribution, and reproduction in any medium, provided the original work is properly cited. Mary Ann Liebert, Inc. offers reprint services for those who want to order professionally produced copies of articles published under the Creative Commons Attribution (CC BY) license. To obtain a price quote, email Reprints@liebertpub.com. Please include the article's title or DOI, quantity, and delivery destination in your email. 
services related to gender transition, nor can they deny health services to an individual if they are available to other patients. Legislative actions to repeal, defund, or delay the implementation of the ACA already risk taking away health insurance from low- and middleincome LGBT Americans; a complete repeal may also erase nondiscrimination protections for transgender Americans. These protections are already being challenged in court and will be further threatened by a repeal of the ACA (at the time of this writing, a U.S. District Court had issued a nationwide injunction on the OCR rule).

Same-Sex Marriage and Discriminatory LGBT Laws Another legacy of the Obama administration has been the federal recognition and implementation of same-sex marriage across the country after the Supreme Court's decisions in United States $v$. Windsor (which overturned the federal definition of marriage between one man and one woman) and Obergefell v. Hodges (which recognized marriage as a constitutional right for same-sex couples). Now that same-sex marriage is legal nationwide, samesex couples are eligible for spousal benefits, including employer-sponsored health insurance, joint tax benefits, social security spousal protections, and healthcare protections, such as hospital visitation rights and medical decision-making for married same-sex couples.

Although President Trump has changed his position on same-sex marriage in the past, Vice President Mike Pence and many congressional Republicans have expressed their disapproval of same-sex marriage and already taken steps to undermine the law. For instance, as Governor of Indiana, Pence signed Indiana's 2015 Religious Freedom Restoration Act (RFRA), which allows individuals and businesses to deny services to LGBT people based on their religious beliefs. Statelevel RFRAs may also allow some clerks and judges to opt out of officiating same-sex marriages. At the time of this writing, 21 states have enacted state-level RFRAs, and another 12 states considered but did not pass RFRA legislation in 2016. ${ }^{6}$ At least five RFRArelated bills have been introduced in 2017 in Colorado (HB1013), Oklahoma (SB530), Hawaii (HB823), Minnesota (HF43), and West Virginia (SB19). ${ }^{6}$

Meanwhile, U.S. Senators Ted Cruz and Mike Lee plan to reintroduce the First Amendment Defense Act, which would prohibit the federal government from taking discriminatory action against a person who believes that (1) marriage is or should be recognized as the union of one man and one woman or
(2) sexual relations are properly reserved to such a marriage. ${ }^{7}$ Such provisions may allow businesses and individuals to discriminate against LGBT people in public and private sector industries, including healthcare settings. Ultimately, although more pro-LGBT bills were introduced and passed in 2016 than anti-LGBT laws, ${ }^{8}$ gains in nondiscrimination protections, relationship recognition, and health and safety remain precarious.

\section{LGBT Health Research Funding}

The field of LGBT health research has grown exponentially, thanks, in part, to a series of new initiatives aimed to increase sponsorship of LGBT health studies by the National Institutes of Health (NIH) and the National Institute on Minority Health and Health Disparities. Specifically, the NIH issued a call for proposals for research on SGMs, ${ }^{9}$ established the Sexual and Gender Minority Research Office, ${ }^{10}$ and, in October 2016, designated SGM people as a health disparity population for research purposes. ${ }^{11}$ This designation broadens funding and research opportunities on LGBT populations and other SGMs.

Despite these advancements, research funding for SGM health is at risk under a Republican Congress and Trump administration. President Trump's proposed budget includes an $18 \%$ cut to the NIH and funding reforms for the Centers for Disease Control and Prevention (CDC), ${ }^{12}$ which would reduce funding available for multiple areas of research, including research at the intersections of sexual orientation, gender identity, and health. Congress may also take a more targeted approach toward reducing funding for LGBT health research. Several legislative attempts in the past have specifically targeted research on human sexuality and health conditions, disproportionately affecting LGBT populations, including HIV/AIDS and other sexually transmitted infections. ${ }^{13}$ In 2003, $150 \mathrm{NIH}$-funded researchers were identified on a "hit list" created by the Traditional Values Coalition for conducting research on risky sexual behaviors, stigmatization of LGBT populations, and substance use among SGMs. ${ }^{14}$ Although this attempt to curtail federal funding of sexuality research was unsuccessful, future legislation may target SGM health for funding freezes.

\section{Discrimination and Stigma}

Individuals espousing anti-LGBT sentiment may be emboldened by the incoming Trump administration. According to the Federal Bureau of Investigations, LGBT people are most likely to be victims of hate 
crimes compared to other minority groups. ${ }^{15}$ In the month after the election, the Southern Poverty Law Center recorded more than 1000 hate crimes against immigrants, racial and ethnic minorities, and LGBT Americans. ${ }^{16}$ Meanwhile, anti-LGBT sentiment persists in many communities. Although public opinion polls suggest that more Americans support same-sex marriage and legal protections for LGBT people, support remains low among older adults, conservatives, and evangelical Protestants. ${ }^{17} \mathrm{New}$ research using the National Inmate Survey also finds that LGBT people are disproportionately incarcerated, mistreated, and sexually victimized in U.S. jails and prisons, suggesting systematic biases against LGBT people at various stages of the criminal justice system. ${ }^{18}$

Public health research consistently finds that antiLGBT discrimination and stigma are associated with worse LGBT health outcomes. Discriminatory acts expose LGBT people to verbal harassment, physical violence, and, in the most extreme cases, death. ${ }^{19}$ Discriminatory public policies-such as same-sex marriage bans ${ }^{20}$ and lack of protections against hate crimes or employmentbased discrimination at the state level ${ }^{21}$-have been associated with worse LGBT health outcomes. These effects are especially pronounced for transgender Americans. The 2015 U.S. Transgender Survey of more than 27,000 transgender adults found that $39 \%$ of respondents experienced serious psychological distress compared with only $5 \%$ of the U.S. population. ${ }^{22}$ Similar health outcomes may worsen under a Trump administration. In the days after the election, LGBT people experienced substantial declines in their life evaluations: the percentage of LGBT adults considered "thriving" dropped 10\% (from $51 \%$ to $41 \%$ ) in the month after the election. ${ }^{23}$

\section{Conclusion}

Donald Trump was sworn in on January 20, 2017, as the 45th President of the United States. In his first year, President Trump may overturn LGBT-affirming policies established by the Obama administration, including an executive order prohibiting federal contractors from discriminating on the basis of sexual orientation or gender identity ${ }^{24}$ and agency guidelines protecting transgender students in public schools from gender identity-based discrimination. ${ }^{25}$ With the assistance of a Republicancontrolled Congress, President Trump may also repeal President Obama's health reform law, reduce funding for research on SGM health, and institutionalize discrimination through new legislation, such as the First Amendment Defense Act.
What can be done? Public health researchers and providers must continue to advocate for LGBT health equity throughout all levels of government and across private sector industries. Healthcare facilities should implement policies prohibiting LGBT-based discrimination, and providers should continue to broaden their awareness on LGBT health issues. In addition, public health researchers should continue to document the effects of evolving public policies on health and access to care for LGBT people. Data collection and rigorous studies on LGBT people are needed more than ever to inform best practices and evidence-based policies for eliminating LGBT health disparities.

In conclusion, the Trump administration portends a sea change for LGBT policy and research. We provide a (nonexhaustive) set of policies that are likely to hinder LGBT health and research. In many ways, the fates of LGBT Americans are intertwined with the millions of Americans at risk of losing health insurance and other protections with the ongoing ACA reform. However, LGBT Americans may face additional barriers and health disparities as a result of explicit policy decisions and discrimination that public health researchers, healthcare providers, and professional organizations must continue to actively address to promote LGBT health equity.

\section{Author Disclosure Statement}

No competing financial interests exist.

\section{References}

1. National Conference of State Legislatures. 2016 Pre- and PostElection State Legislative Control. 2016. Available at www.ncsl.org/research/ elections-and-campaigns/2016-pre-and-postelection-state-legislativecontrol.aspx Accessed April 2, 2017.

2. Congressional Budget Office. Federal Subsidies for Health Insurance Coverage for People Under Age 65: 2016 to 2026. 2016. Available at www.cbo.gov/sites/default/files/114th-congress-2015-2016/reports/ 51385-HealthInsuranceBaseline_OneCol.pdf (accessed January 9, 2017).

3. Baker K, Durso LE, Cray A. Moving the Needle: The Impact of the Affordable Care Act on LGBT Communities. Washington, DC: Center for American Progress. 2014. Available at https://cdn.americanprogress.org/ wp-content/uploads/2014/11/LGBTandACA-report.pdf (accessed January 9, 2017).

4. Skopec L, Long SK. Lesbian, gay, and bisexual adults making gains in health insurance and access to care. Health Aff. 2015;34:1769-1773.

5. Baker K. LGBT Protections In Affordable Care Act Section 1557. Health Affairs Blog. 2016. Available at http://healthaffairs.org/blog/2016/06/06/ lgbt-protections-in-affordable-care-act-section-1557 (accessed January 9, 2017).

6. American Civil Liberties Union. Past anti-LGBT religious exemption legislation across the country. 2017. Available at www.aclu.org/other/pastanti-lgbt-religious-exemption-legislation-across-country\#rfra16 Accessed April 7, 2017.

7. Labrador R. H.R.2802 First Amendment Defense Act. 2015. Available at www.congress.gov/bill/114th-congress/house-bill/2802. Accessed December 21, 2016.

8. Human Rights Campaign. 2016 State Equality Index. Washington, DC. 2016. 
9. Alexander R, Parker K, Schwetz T. Sexual and gender minority health research at the National Institutes of Health. LGBT Health. 2016;3: 7-10.

10. National Institutes of Health Sexual and Gender Minority Research Coordinating Committee. Strategic Plan to Advance Research on the Health and Well-Being of Sexual and Gender Minorities.Washington, DC. 2015 .

11. Perez-Stable EJ. Sexual and Gender Minorities Formally Designated as a Health Disparity Population for Research Purposes. National Institute of Minority Health and Health Disparities. 2016. Avilable at www.nimhd.nih.gov/about/directors-corner/message.html Accessed October 24, 2016

12. Harris R, Stein R. Trump Administration Proposes Big Cuts In Medical Research. National Public Radio. 2017. Available at www.npr.org/sections/ health-shots/2017/03/16/520390147/trump-administration-proposesbig-cuts-in-medical-research Accessed April 7, 2017.

13. Epstein $\mathrm{S}$. The new attack on sexuality research: morality and the politics of knowledge production. Sex Res Soc Policy. 2006;3:1-12.

14. Studwell K. Sexual Health Grants Targeted by Conservative Group. Psychological Science Agenda. 2003. Available at www.apa.org/science/about/ psa/2003/11/sexual-health.aspx Accessed December 21, 2016.

15. Federal Bureau of Investigation. Hate Crime Statistics, 2015. Available at https://ucr.fbi.gov/hate-crime/2015 Accessed April 2, 2017.

16. Southern Law Poverty Center. Update: 1,094 Bias-Related Incidents in the Month Following the Election. Available at www.splcenter.org/ hatewatch/2016/12/16/update-1094-bias-related-incidents-monthfollowing-election Accessed December 21, 2016.

17. Pew Research Center. Public Opinion on Gay Marriage in the U.S. 2016 Available at www.pewforum.org/2016/05/12/changing-attitudes-on-gaymarriage Accessed December 21, 2016.

18. Meyer IH, Flores AR, Stemple $\mathrm{L}$, et al. Incarceration rates and traits of sexual minorities in the United States: National Inmate Survey, 20112012. Am J Public Health. 2016:e1-e7.

19. National Coalition of Anti-Violence Programs. An Open Letter from LGBTQ Organizations. 2015. Available at http://avp.org/storage/ documents/webversion_ncavp_ma_national2015.pdf (accessed January 9, 2017)
20. Kail BL, Acosta KL, Wright ER. State-level marriage equality and the health of same-sex couples. Am J Public Health. 2015;105:1101-1105.

21. Blosnich JR, Marsiglio MC, Gao S, et al. Mental health of transgender veterans in US States with and without discrimination and hate crime legal protection. Am J Public Health. 2016:e1-e7.

22. James SE, Herman JL, Rankin S, et al. The Report of the 2015 US Transgender Survey. Washington, DC: National Center for Transgender Equality. 2016.

23. Gates G. Life Evaluations of LGBT Americans Decline After Election. Gallup. 2016. Available at www.gallup.com/poll/199439/lgbt-status-partywed-mid.aspx Accessed December 21, 2016.

24. The White House. President Obama Signs a New Executive Order to Protect LGBT Workers. 2014. Available at www.whitehouse.gov/blog/ 2014/07/21/president-obama-signs-new-executive-order-protect-lgbtworkers Accessed December 21, 2016.

25. U.S. Departments of Education and Justice Release Joint Guidance to Help Schools Ensure the Civil Rights of Transgender Students. US Department of Education. 2016. Available at www.ed.gov/news/press-releases/usdepartments-education-and-justice-release-joint-guidance-help-schoolsensure-civil-rights-transgender-students Accessed December 21, 2016.

Cite this article as: Gonzales G, McKay T (2017) What an emerging Trump administration means for lesbian, gay, bisexual, and transgender health, Health Equity 1:1, 83-86, DOI: 10.1089/heq.2017.0002.

$\begin{aligned} & \text { Abbreviations Used } \\ & \mathrm{ACA}=\text { Affordable Care Act } \\ & \mathrm{CDC}=\text { Centers for Disease Control and Prevention } \\ & \mathrm{NIH}=\text { National Institutes of Health } \\ & \mathrm{OCR}=\text { Office for Civil Rights } \\ & \mathrm{SGMs}=\text { sexual and gender minorities }\end{aligned}$

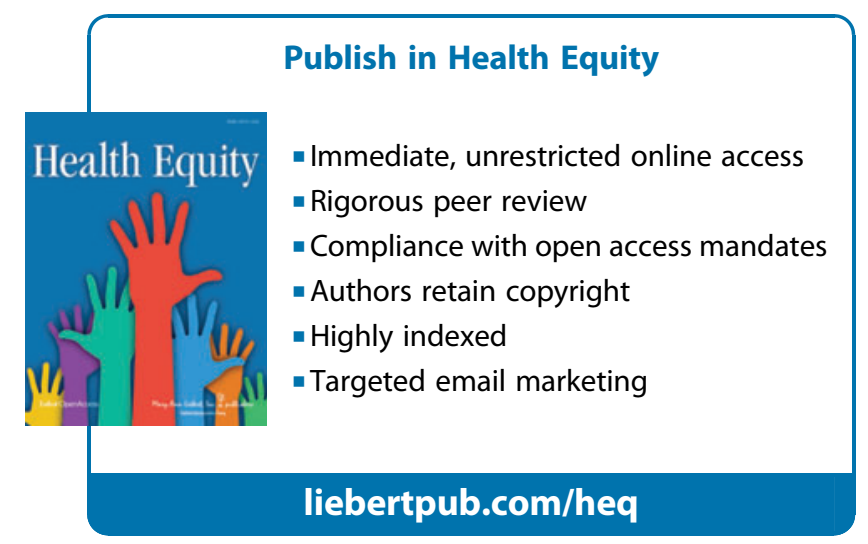

